Check for updates

Cite this: Phys. Chem. Chem. Phys., 2020, 22, 18891

Received 5th February 2020, Accepted 17th April 2020

DOI: 10.1039/d0cp00654h

rsc.li/pccp

\section{Development of photochemical and electrochemical cells for operando X-ray absorption spectroscopy during photocatalytic and electrocatalytic reactions $\dagger$}

\author{
Rachit Khare, (D) ${ }^{a}$ Andreas Jentys ${ }^{\star a}$ and Johannes A. Lercher ${ }^{\mathrm{ab}}$
}

\begin{abstract}
Photochemical and electrochemical reactions are highly relevant processes for (i) transforming chemicals (e.g. photoreduction of isopropanol to acetone, electrochemical hydrogenation of benzaldehyde to benzyl alcohol, etc.), and (ii) sustainable energy production (e.g. photoreduction of $\mathrm{CO}_{2}$ to methanol, electrocatalytic $\mathrm{H}_{2}$ evolution reaction). It is therefore of importance to monitor the structural changes and to understand the properties of active sites under photocatalytic and electrocatalytic reaction conditions. Operando X-ray absorption spectroscopy (XAS) provides the means to investigate the nature of active sites under realistic reaction conditions. In this contribution, we describe the successful development of photochemical and electrochemical cells for operando XAS measurements during photocatalytic and electrocatalytic reactions. We have used the operando photochemical cell to monitor the formation of Pt nanoparticles on graphitic carbon nitride nanosheets $\left(\mathrm{g}-\mathrm{C}_{3} \mathrm{~N}_{4}-\mathrm{ns}\right)$ via photodeposition under visible light illumination and observed the formation of highly dispersed Pt nanoparticles with an estimated size of $\sim 2.5 \mathrm{~nm}$ and $>60 \%$ dispersion. We have also tested this cell to follow the oxidation state of $\mathrm{Pt}$ in $\mathrm{Pt} / \mathrm{TiO}_{2}$ and $\mathrm{Pt} / \mathrm{g}-\mathrm{C}_{3} \mathrm{~N}_{4}$-ns during $\mathrm{H}_{2}$ evolution reaction (HER). We observed that Pt predominantly existed as metallic (reduced) $\mathrm{Pt}^{0}$ species under HER conditions, and that $\mathrm{PtO}_{x}$ species were partially reduced from $\mathrm{Pt}^{\mathrm{IV}}$ to $\mathrm{Pt}^{\mathrm{O}}$ upon illumination with $\mathrm{UV}$ or visible light. The rates of $\mathrm{H}_{2}$ evolution obtained in the photochemical cell (12.1 mmol g ${ }^{-1} \mathrm{~h}^{-1}$ on $\mathrm{Pt} / \mathrm{TiO}_{2}$ and $1.01 \mathrm{mmol} \mathrm{g}{ }^{-1} \mathrm{~h}^{-1}$ on $\mathrm{Pt} / \mathrm{g}-\mathrm{C}_{3} \mathrm{~N}_{4}-\mathrm{ns}$ ) were comparable to that obtained in a standard top-irradiated photoreactor $\left(16.6 \mathrm{mmol} \mathrm{g}^{-1} \mathrm{~h}^{-1}\right.$ on Pt/TiO $\mathrm{T}_{2}$ and $1.76 \mathrm{mmol} \mathrm{g} \mathrm{g}^{-1} \mathrm{~h}^{-1}$ on $\left.\mathrm{Pt} / \mathrm{g}-\mathrm{C}_{3} \mathrm{~N}_{4}-\mathrm{ns}\right)$. The operando electrochemical cell was successfully tested to monitor the changes in the structure and oxidation state of $\mathrm{Pd}$ in $\mathrm{Pd} / \mathrm{C}$ electrocatalyst during electrocatalytic hydrogenation $(\mathrm{ECH})$ of benzaldehyde. It was demonstrated that $\mathrm{Pd}$ in $\mathrm{Pd} / \mathrm{C}$ was present in a partially reduced state $\left(\sim 80 \% \mathrm{Pd}^{0}\right.$ and $\left.\sim 20 \% \mathrm{Pd}^{\prime \prime}\right)$ and $\mathrm{Pd}$ nanoparticles did not degrade upon the application of an external potential under $\mathrm{ECH}$ reaction conditions.
\end{abstract}

\section{Introduction}

The development of cells for operando X-ray absorption spectroscopy (XAS) experiments is essential to follow the chemical state and the structural properties of catalytically active materials under realistic reaction conditions. A large number of designs have been developed and successfully applied for gas-phase and liquid-phase reactions, ${ }^{1-12}$ photochemical reactions, ${ }^{13-21}$ or electrochemical reactions. ${ }^{2-41}$ However, only a few designs

\footnotetext{
${ }^{a}$ Department of Chemistry and Catalysis Research Center, Technical University of Munich, Garching, Germany. E-mail: jentys@tum.de

${ }^{b}$ Institute for Integrated Catalysis, Pacific Northwest National Laboratory, Richland, USA

$\dagger$ Electronic supplementary information (ESI) available. See DOI: 10.1039/ d0cp00654h
}

capable of performing operando XAS measurements for heterogeneous photochemical or electrochemical reactions have been discussed or described in detail. The main challenges associated with such cells is that the photocatalytic and electrocatalytic reactions are typically carried out in liquid phase at the solid-liquid interface and that the catalyst has to be exposed to UV/visible irradiation (in photocatalysis) or to an external potential (in electrocatalysis). The presence of the liquid phase on its own represents a challenge due to the high absorbing background, but the additional constraints due to the external excitation with UV/visible light or electrons leads to further constraints in the cell design.

Our design principle is based on a modular design, where the catalyst is deposited on an X-ray transparent glassy carbon window which can either be illuminated with a UV/visible LED lamp (for photocatalysis applications) or is directly used as a 
conducting electrode (for electrocatalysis applications). To supply the cell with reactants and to remove the products for online analyses, a gas-dosing and gas/liquid-recirculation setup was developed, which is highly modular and can be used either in the laboratory or directly at the beamline for operando XAS measurements. To demonstrate the potential of the photochemical cell, we studied photodeposition of $\mathrm{Pt}$ nanoparticles on graphitic carbon nitride nanosheets $\left(\mathrm{Pt} / \mathrm{g}-\mathrm{C}_{3} \mathrm{~N}_{4}-\mathrm{ns}\right)$ under visible light irradiation, and monitored the changes in the oxidation state of $\mathrm{Pt}$ in $\mathrm{Pt} / \mathrm{TiO}_{2}$ or $\mathrm{Pt} / \mathrm{g}-\mathrm{C}_{3} \mathrm{~N}_{4}-\mathrm{ns}$ under $\mathrm{H}_{2}$ evolution reaction (HER) conditions. The operando electrochemical setup was tested for electrochemical hydrogenation (ECH) of aqueous benzaldehyde solution over Pd/C electrocatalyst. Our experiments successfully demonstrated that these operando cells can be reliably used to (i) determine the oxidation state of active species, and (ii) monitor structural changes in the active species, under photocatalytic or electrocatalytic reaction conditions.

\section{Experimental section}

\subsection{Materials}

Following materials and chemicals were obtained from commercial suppliers and were used as-received without further modifications: $\mathrm{TiO}_{2}$ (Sigma-Aldrich, Degussa Aeroxide ${ }^{\circledR}$ P25, typically composed of $\sim 75 \%$ anatase and $\sim 25 \%$ rutile phases), ${ }^{42,43}$ dicyandiamide (Sigma-Aldrich, 99\%), $\mathrm{H}_{2} \mathrm{PtCl}_{6}$ aqueous solution (Sigma-Aldrich, $8 \mathrm{wt} \%$ in $\mathrm{H}_{2} \mathrm{O}$ ), methanol (Sigma-Aldrich, 99.8\% anhydrous), Pd/C (Sigma-Aldrich, 5 wt\% Pd-loading, activated carbon support), Pt/C (Sigma-Aldrich, $5 \mathrm{wt} \%$ Pt-loading, activated carbon support), acetic acid/sodium acetate buffer solution (Sigma-Aldrich, $\mathrm{pH} \sim 4.6$ ). The Nafion ${ }^{\circledR}$ proton exchange membrane (Sigma-Aldrich) was treated in $\mathrm{H}_{2} \mathrm{O}_{2}$ solution (3 vol\%) and sulfuric acid ( $2 \mathrm{M}$ ) before use. The following materials were used as references in XAS measurements: $\mathrm{Pt}^{0}$-foil (Exafs Materials), $\mathrm{Pd}^{0}$-foil (Exafs Materials), $\mathrm{Pt}^{\mathrm{IV}} \mathrm{O}_{2} \cdot \mathrm{H}_{2} \mathrm{O}$ (SigmaAldrich, 99.9\% trace metal basis), and $\mathrm{Pd}^{\mathrm{II}} \mathrm{O}$ (Sigma-Aldrich, 99.97\% trace metal basis).

\subsection{Catalyst preparation}

2.2.1 Synthesis of bulk graphitic carbon nitride. Graphitic carbon nitride $\left(\mathrm{g}-\mathrm{C}_{3} \mathrm{~N}_{4}\right)$ bulk material was synthesized via thermal polymerization of dicyandiamide. ${ }^{44}$ Typically, $\sim 10 \mathrm{~g}$ dicyandiamide was placed in an alumina crucible (SigmaAldrich, Coors ${ }^{\mathrm{TM}}$ ) covered with a lid. The crucible was placed in a muffle furnace and heated to $823 \mathrm{~K}$ at a rate of $10 \mathrm{~K} \mathrm{~min}^{-1}$. The temperature was held at $823 \mathrm{~K}$ for $4 \mathrm{~h}$ before naturally cooling down to room temperature. The obtained powder was yellow in color. It was washed with $0.1 \mathrm{M} \mathrm{HCl}$, followed by $0.1 \mathrm{M} \mathrm{NaOH}$, and then several times with deionized water. The powder was dried overnight in an oven at $353 \mathrm{~K}$ and crushed to a fine powder.

2.2.2 Synthesis of graphitic carbon nitride nanosheets. g- $\mathrm{C}_{3} \mathrm{~N}_{4}$ nanosheets $\left(\mathrm{g}-\mathrm{C}_{3} \mathrm{~N}_{4}\right.$-ns) were synthesized via thermal exfoliation of $\mathrm{g}-\mathrm{C}_{3} \mathrm{~N}_{4}$ bulk material. ${ }^{45}$ In a typical synthesis, $\sim 2 \mathrm{~g}$ bulk $\mathrm{g}-\mathrm{C}_{3} \mathrm{~N}_{4}$ was placed in an open alumina crucible without a lid. The crucible was then placed in a muffle furnace and heated to $773 \mathrm{~K}$ at a rate of $10 \mathrm{~K} \mathrm{~min}^{-1}$. The temperature was held at $773 \mathrm{~K}$ for $3 \mathrm{~h}$ before naturally cooling down to room temperature. The obtained powder was light yellow in color and is denoted as $\mathrm{g}-\mathrm{C}_{3} \mathrm{~N}_{4}$-ns.

2.2.3 Synthesis of Pt-loaded photocatalysts. Pt was deposited on $\mathrm{g}-\mathrm{C}_{3} \mathrm{~N}_{4}$-ns or $\mathrm{TiO}_{2}$ via photodeposition using a conventional top-irradiated photoreactor (see Fig. S1 in the ESI $\dagger$ ). Typically, $100 \mathrm{mg}$ g- $\mathrm{C}_{3} \mathrm{~N}_{4}$-ns or $\mathrm{TiO}_{2}$ was suspended in $45 \mathrm{~mL}$ deionized water. The suspension was ultrasonicated for $30 \mathrm{~min}$ to disperse the photocatalyst before being placed in the photoreactor. Appropriate amounts of $\mathrm{H}_{2} \mathrm{PtCl}_{6}$ (corresponding to $0.5 \mathrm{wt} \%$ Pt-loading) and methanol (corresponding to $10 \mathrm{vol} \%$ ) were added. The catalyst suspension was stirred continuously. The photoreactor was sealed and flushed several times with Ar to remove any residual gases. The system was finally pressurized to 1 bar with $\mathrm{Ar}$ and reactor temperature was maintained at $298 \mathrm{~K}$ using cooling water supply. The gas-phase was analyzed using an online Shimadzu 2010 Plus gas chromatograph (GC) equipped with a Restek ShinCarbon packed column, a thermal conductivity detector (TCD), a flame ionization detector (FID), and a Ni-based methanizer unit. Illumination was provided with a $405 \mathrm{~nm} 4.4 \mathrm{~W}$ visible light LED lamp (for photodeposition on $\mathrm{g}-\mathrm{C}_{3} \mathrm{~N}_{4}-\mathrm{ns}$ ) or with a $365 \mathrm{~nm} 5 \mathrm{~W}$ UV light LED lamp (for photodeposition on $\mathrm{TiO}_{2}$ ). The photodeposition was typically carried out for $120 \mathrm{~min}$ or until the observed $\mathrm{H}_{2}$ evolution rate was constant.

\subsection{Catalyst characterization}

The synthesized materials were characterized using elemental analyses, $\mathrm{N}_{2}$ adsorption-desorption measurements, powder X-ray diffraction (XRD), and UV-visible diffuse reflectance spectroscopy (UV-vis DRS). The applied characterization techniques are described in detail in the ESI. $\dagger$

\subsection{Photocatalytic activity measurements}

The photocatalytic activity of $\mathrm{Pt} / \mathrm{g}-\mathrm{C}_{3} \mathrm{~N}_{4}-\mathrm{ns}$ and $\mathrm{Pt} / \mathrm{TiO}_{2}$ were determined for HER in a conventional top-irradiated photoreactor (see Fig. S1 in the ESI $\dagger$ ). In a typical experiment, $\sim 50 \mathrm{mg}$ photocatalyst was dispersed in $45 \mathrm{~mL}$ deionized water and ultrasonicated for $30 \mathrm{~min}$. The catalyst suspension was placed in the photoreactor and $5 \mathrm{~mL}$ methanol was added. The entire setup was flushed several times with Ar to remove any residual gases. All reactions were carried out at $298 \mathrm{~K}$ and under 1 bar Ar pressure. Illumination was provided either by a visible light (405 nm $4.4 \mathrm{~W}$ ) or a UV light (365 nm $5 \mathrm{~W}$ ) LED lamp. Gas-phase was continuously analyzed using an online GC. Data points were collected at $20 \mathrm{~min}$ intervals for up to $120 \mathrm{~min}$.

\subsection{X-ray absorption spectroscopy measurements}

X-ray absorption spectra were collected at the P65 beamline of the German electron synchrotron (DESY) in Hamburg, Germany. The PETRA III storage ring was operated at $6 \mathrm{GeV}$ energy and $100 \mathrm{~mA}$ beam current in top-up mode. A watercooled Si111 (for Pt $\mathrm{L}_{\mathrm{III}}$-edge) or Si311 (for Pd K-edge) double crystal monochromator (DCM) was used for obtaining 

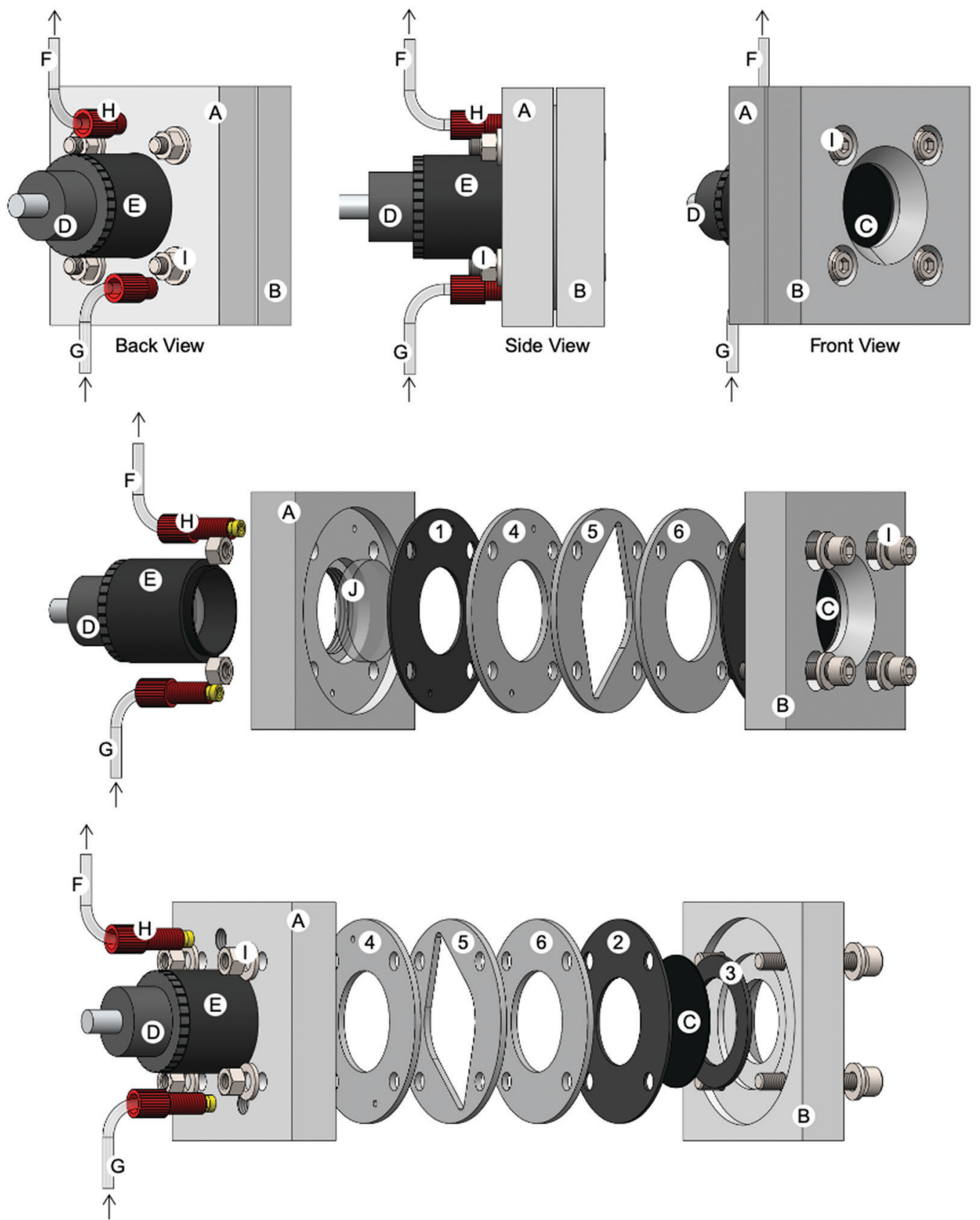

Fig. 1 Exploded view of the photochemical cell for XAS measurements during photocatalytic reactions or photodeposition studies. (A) PTFE back-cover, (B) PTFE front-cover, (C) $500 \mu \mathrm{m}$ thick glassy carbon window (HTW Germany) coated with the catalyst, (D) UV or visible light LED lamp (Prizmatix) equipped with an optical guide, and (E) collimator lens (Prizmatix), ( F and G) PTFE liquid inlet and outlet, (H) PEEK flangeless fittings (IDEX Optofluidic Systems), (I) stainless steel nuts, bolts, and washers, (J) UV/vis transparent quartz window (Edmund Optics), (1-3) rubber sealing gaskets, (4-6) flow path created using $2 \mathrm{~mm}$ thick PTFE sheets (Garlock).

monochromatic X-rays. Two Rh-coated plane mirrors were installed in front of the DCM to reject higher harmonics. ${ }^{46}$ The DCM was calibrated for Pt $\mathrm{L}_{\mathrm{III}}$-edge measurements by measuring a Pt-foil and defining the first inflection point as $11564 \mathrm{eV}$. Similarly, the DCM was calibrated for Pd K-edge measurements by measuring a Pd-foil and setting the first inflection point to $24350 \mathrm{eV}$. The corresponding metal foils were placed between the second and third ionization chamber for the energy calibration of each measured spectrum.
The energy resolution of the beamline is estimated to be $\sim 1.6 \mathrm{eV}$ at the Pt $\mathrm{L}_{\mathrm{III}}$-edge and $\sim 1.5 \mathrm{eV}$ at the Pd K-edge. X-ray absorption near edge structure (XANES) and extended X-ray absorption fine structure (EXAFS) analyses were performed using Athena and Artemis software packages. ${ }^{47}$

\subsection{Operando photochemical experiments}

XAS measurements during photochemical reactions were performed at $\mathrm{Pt}_{\mathrm{LIII}}$-edge (11564 eV) in fluorescence mode using a 
passivated implanted planar silicon (PIPS) detector. The spot-size of X-ray beam at the sample was $1.4 \mathrm{~mm}$ (horizontal) $\times$ $600 \mu \mathrm{m}$ (vertical). XANES were measured between $-100 \mathrm{eV}$ and $+400 \mathrm{eV}$ around the $\mathrm{Pt} \mathrm{L}_{\mathrm{III}}$-edge in continuous scanning mode. The spectra for EXAFS were measured between $-150 \mathrm{eV}$ and $+1000 \mathrm{eV}$ around the $\mathrm{Pt} \mathrm{L}_{\mathrm{III}}$-edge in step scanning mode. For XANES analyses, $E_{0}$ was fixed at $11564 \mathrm{eV}$ and the spectra were normalized and flattened. For EXAFS analyses, spectra were background subtracted, normalized, $k^{3}$-weighted, and Fourier-transformed in the $k$ range of $3-15 \AA^{-1}$. The EXAFS data was fitted to Pt fcc structure in $R$-space between 1.5-3.5 $\AA$ (corresponding to the first coordination shell).

2.6.1 The photochemical setup. A schematic of the photochemical cell used for operando XAS measurements is shown in Fig. 1. The cell comprises of a back-cover and a front-cover constructed out of PTFE. The back-cover features two ports for liquid inlet and outlet, and a UV/vis transparent quartz window for allowing illumination with UV or visible light. The frontcover features an X-ray transparent glassy carbon window coated with the photocatalyst for XAS measurements in fluorescence mode. Typically, $5 \mathrm{mg}$ catalyst was dispersed in $200 \mu \mathrm{L}$ isopropanol and ultrasonicated for $30 \mathrm{~min}$ to create an ink. The ink was coated onto the glassy carbon window and the substrate was dried at $353 \mathrm{~K}$ for $2 \mathrm{~h}$. The cell features a flow path constructed out of $2 \mathrm{~mm}$ thick PTFE sheets for liquid flow across the catalyst surface. The cell was sealed using rubber gaskets and stainless-steel nuts and bolts.

The operando XAS measurements were performed in the photochemical cell using a gas-dosing and gas/liquidrecirculation setup as illustrated in Fig. 2. The setup consists of a liquid reservoir placed inside an aluminum cooling jacket. A recirculating chiller unit was used to continuously circulate cooling water (CW) and maintain the desired reaction temperature.
The reservoir was covered with a lid featuring several inlet and outlet ports. Gas flow rates were controlled using mass flow controllers, and a pressure meter was used to monitor the pressure. The gases were recirculated using a double diaphragm gas pump. The liquid was recirculated between the liquid reservoir and the photochemical cell using a liquid gear pump.

2.6.2 Photocatalytic reactions. For photocatalytic reactions, $\mathrm{Pt} / \mathrm{g}-\mathrm{C}_{3} \mathrm{~N}_{4}$-ns or $\mathrm{Pt} / \mathrm{TiO}_{2}$ were coated onto the glassy carbon window. Typically, $50 \mathrm{~mL}$ methanol aqueous solution (10 vol\%) was added to the liquid reservoir. The system was flushed with Ar several times to remove any residual gases. The setup was pressurized with Ar to 1 bar. All reactions were carried out at $298 \mathrm{~K}$ in recirculation mode. XANES spectra were measured every 90 seconds in continuous scanning mode. Several measurements were taken before illumination. The LED light source was switched on remotely and several spectra were measured during illumination. The measurements were stopped when no spectral changes were observed upon further illumination. In separate experiments carried out in the laboratory, photocatalytic activity of Pt/g- $\mathrm{C}_{3} \mathrm{~N}_{4}$-ns and Pt/TiO ${ }_{2}$ for HER was determined using the operando photochemical setup. During these experiment, gas-phase was continuously analyzed using an online GC. Data points were collected at $20 \mathrm{~min}$ intervals for up to $120 \mathrm{~min}$.

2.6.3 Photodeposition studies. For photodeposition, g- $\mathrm{C}_{3} \mathrm{~N}_{4}$-ns was coated on the glassy carbon window. $\mathrm{H}_{2} \mathrm{PtCl}_{6}$ aqueous solution was used as a metal precursor. The cell was assembled using the same procedure as described in Section 2.6.2. XANES spectra were continuously measured before and during illumination. Measurements were stopped when no significant changes were observed in the spectra upon further illumination. The cell was then drained of the residual

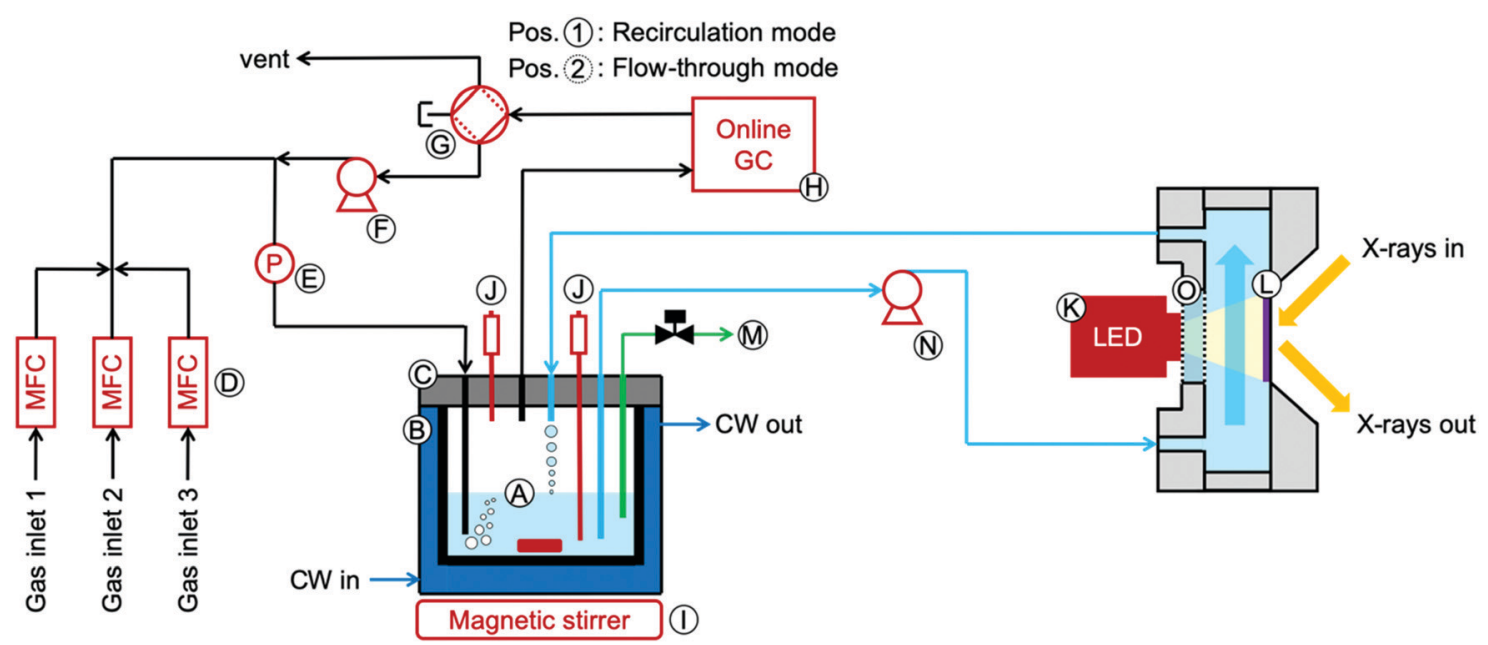

Fig. 2 Gas-dosing and gas/liquid-recirculation setup for operando XAS measurements during photocatalytic reactions and photodeposition studies. (A) PTFE liquid reservoir, (B) aluminum cooling jacket connected to a recirculating chiller unit (Julabo), (C) PTFE lid with several inlet and outlet ports, (D) mass flow controllers (Bronkhorst), (E) pressure meter (Bronkhorst), (F) double diaphragm gas pump (KNF Neuberger), (G) switching valve (VICI Valco), (H) online GC (Shimadzu 2010 Plus), (I) magnetic stirrer (ThermoFischer), (J) K-type thermocouples (Omega), (K) UV or visible light LED source equipped with an optical guide and a collimator lens (Prizmatix), (L) $500 \mu \mathrm{m}$ thick glassy carbon window (HTW Germany) coated with the catalyst, (M) liquid sampling port, (N) liquid gear pump (Ismatec), and (O) quartz window (Edmund Optics). 

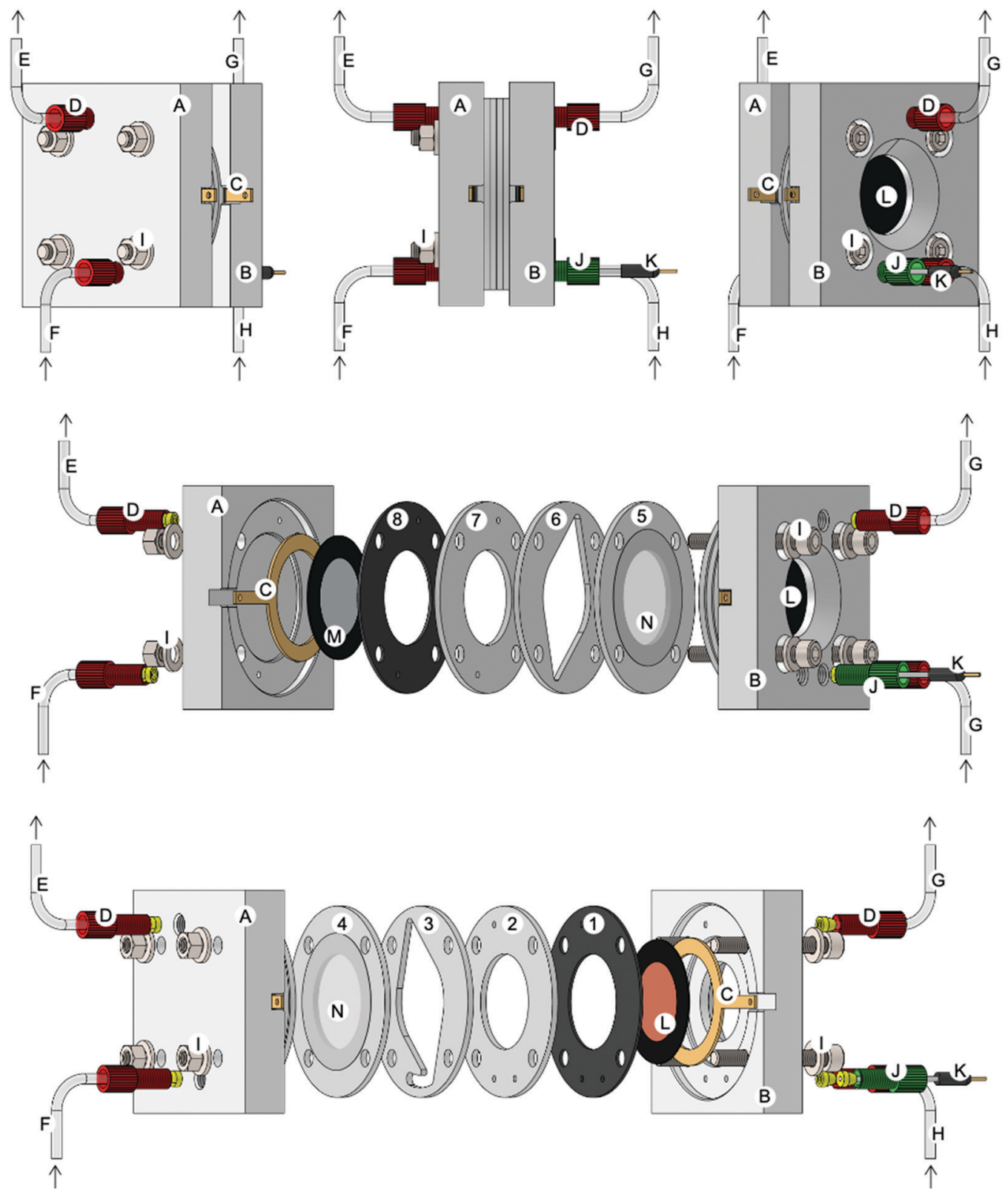

Fig. 3 Exploded view of the electrochemical cell for operando XAS measurements during electrocatalytic reactions. (A) PTFE counter electrode cover, (B) PTFE working electrode cover, (C) titanium electrical connectors, (D) PEEK flangeless fittings (IDEX Optofluidic Systems), (E-H) PTFE electrolyte inlets and outlets, (I) stainless-steel nuts, bolts, and washers, (J) flangeless fitting (IDEX Optofluidic Systems), for (K) Ag/AgCl leakless reference electrode (eDAQ), ( $L$ and M) $500 \mu \mathrm{m}$ thick glassy carbon windows (HTW Germany) coated with electrocatalyst, (N) Nafion ${ }^{\mathbb{R}}$ perfluorinated proton-exchange membrane (Sigma-Aldrich), (2-7) flow path constructed out of $2 \mathrm{~mm}$ thick PTFE sheets (Garlock), and (1 and 8) rubber sealing gaskets.

solution, and EXAFS measurements were performed on dry $\mathrm{Pt} / \mathrm{g}-\mathrm{C}_{3} \mathrm{~N}_{4}$-ns catalyst.

\subsection{Operando electrochemical experiments}

XAS measurements during electrochemical reactions were performed at the Pd K-edge $(24350 \mathrm{eV})$ in fluorescence mode using a 7-element high purity germanium (HPGe) detector. The spot size of the X-ray beam at the sample was $1.4 \mathrm{~mm}$ (horizontal) $\times$ $200 \mu \mathrm{m}$ (vertical). All spectra were measured between $-100 \mathrm{eV}$ and $+400 \mathrm{eV}$ around the Pd K-edge in step scanning mode. For XANES analyses, $E_{0}$ was fixed at $24350 \mathrm{eV}$ and spectra were normalized and flattened. For EXAFS analyses, spectra were background subtracted, normalized, $k^{3}$-weighted, and Fouriertransformed in the $k$ range of $3-10 \AA^{-1}$. The data was fitted to Pd fcc structure in $R$-space between 1.5-3.0 $\AA$ (corresponding to the first coordination shell).

2.7.1 The electrochemical setup. With a few modifications, the photochemical cell together with a modified gas-dosing and gas/liquid-recirculation setup was used for operando XAS measurements during electrochemical experiments. Fig. 3 shows a schematic of the operando electrochemical cell. The cell comprises of a working-electrode and a counter-electrode 
chamber separated by an ion-exchange membrane. The workingelectrode cover contains two ports for inlet and outlet of the electrolyte and one port for inserting a reference electrode. The counter-electrode cover also contains two ports for the inlet and outlet of the electrolyte. The cell features an X-ray transparent glassy carbon window coated with an electrocatalyst (acting as the working electrode) and a similar counter electrode. The glassy carbon electrodes were connected to a voltage supply unit using titanium electrical connectors. The cell also features a flow path in the working- and counter-electrode chambers constructed out of $2 \mathrm{~mm}$ thick PTFE sheets. The cell was sealed using rubber gaskets and stainless-steel nuts and bolts.

A schematic of the modified gas-dosing and gas/liquidrecirculation setup for electrochemical experiments is shown in Fig. 4. The setup features two electrolyte reservoirs for the working electrode and the counter electrode chambers, respectively. The reservoirs are constructed out of PTFE and feature several ports for gas and liquid inlet and outlet. The reservoirs are enclosed inside aluminum cooling jackets connected to a recirculating chiller unit. The electrolyte was recirculated between the liquid reservoirs and the electrochemical cell using liquid gear pumps. Gases were supplied to the reservoirs using mass flow controllers. A switching valve was used to switch between recirculation mode and flowthrough mode. Temperature of the liquid and gas phase was monitored using K-type thermocouples. The pressure was continuously monitored using pressure meters. The electrolyte reservoirs also feature ports for sampling the liquid during the reaction for further analyses.
2.7.2 Electrochemical hydrogenation of benzaldehyde. For electrochemical reactions, a glassy carbon window coated with $\mathrm{Pd} / \mathrm{C}$ was used as the working electrode (cathode) and a $\mathrm{Pt} / \mathrm{C}$ coated glassy carbon window was used as the counter electrode (anode). Acetic acid/sodium acetate buffer solutions $(\sim 50 \mathrm{~mL})$ were used as catholyte and anolyte solutions and were placed in the respective liquid reservoirs. The system was flushed with Ar several times to remove any residual gases. All reactions were carried out at $298 \mathrm{~K}$ in flow-through mode. Prior to the reaction, cathode was polarized under constant current of $-40 \mathrm{~mA}$ for $30 \mathrm{~min}$. Benzaldehyde was added to the catholyte before the reaction to obtain a final concentration of $20 \mathrm{mmol} \mathrm{L}^{-1}$. The uncompensated resistance ( $i R$ drop) was determined by potentiostatic electrochemical impedance spectroscopy (PEIS). The applied potentials were corrected using the value obtained therein. Electrochemical hydrogenation $(\mathrm{ECH})$ of benzaldehyde was carried out at a constant applied potential of up to $-600 \mathrm{mV}(v s$. $\mathrm{Ag} / \mathrm{AgCl}$ reference electrode). XANES and EXAFS measurements were performed under open circuit voltage (OCV) conditions and under $\mathrm{ECH}$ reaction conditions.

\section{Results and discussion}

\subsection{Catalyst characterization}

The results of elemental analyses, $\mathrm{N}_{2}$ adsorption-desorption measurements, powder XRD, and UV-vis DRS measurements, are presented in detail in the ESI. $\dagger$

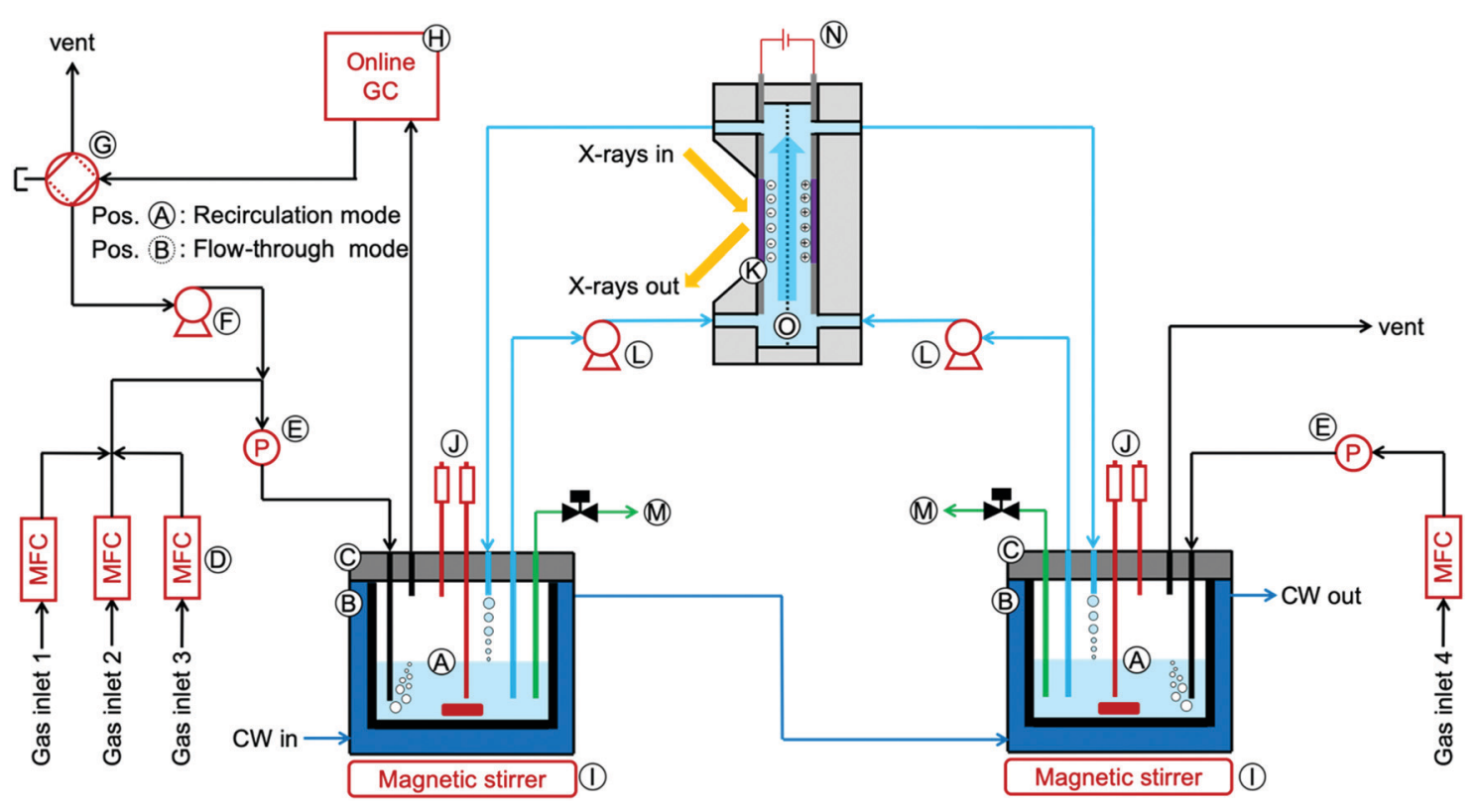

Fig. 4 Gas-dosing and gas/liquid-recirculation setup for operando XAS measurements during electrocatalytic reactions. (A) PTFE electrolyte reservoirs, (B) aluminum cooling jackets connected to a recirculating chiller unit (Julabo), (C) PTFE lid with several inlet and outlet ports, (D) mass flow controllers (Bronkhorst), (E) pressure meters (Bronkhorst), (F) double diaphragm gas pump (KNF Neuberger), (G) switching valve (VICl Valco), (H) online GC (Shimadzu 2010 Plus), (I) magnetic stirrer (ThermoFischer), (J) K-type thermocouples (Omega), (K) $500 \mu \mathrm{m}$ thick glassy carbon windows (HTW Germany) coated with electrocatalyst, (L) liquid gear pumps (Ismatec), (M) liquid sampling ports, (N) voltage supply unit (BioLogic VSP-300), and (O) Nafion ${ }^{\circledR}$ perfluorinated proton-exchange membrane (Sigma-Aldrich). 

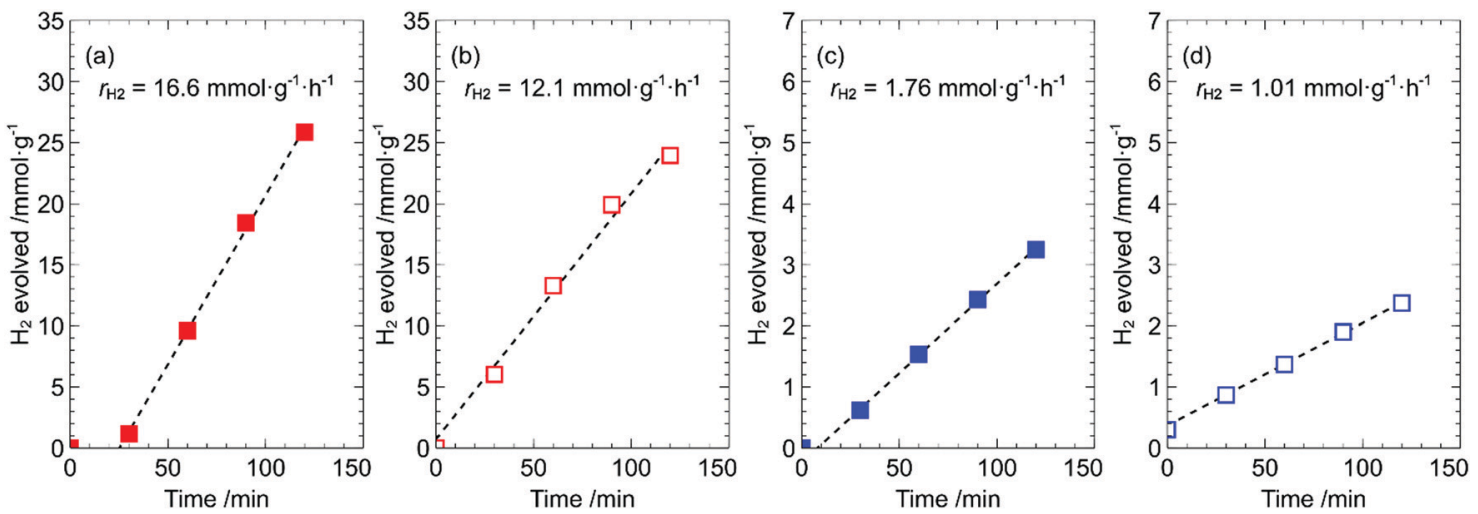

Fig. $5 \mathrm{H}_{2}$ evolved (in mmol g ${ }^{-1}$ ), as a function of time, during $\mathrm{HER}$, on (a) $\mathrm{Pt} / \mathrm{TiO}_{2}$, (b) $\mathrm{Pt} / \mathrm{TiO}_{2}$ (in the operando photochemical cell), (c) Pt/g- $\mathrm{C}_{3} \mathrm{~N}_{4}$-ns, and (d) $\mathrm{Pt} / \mathrm{g}-\mathrm{C}_{3} \mathrm{~N}_{4}$-ns (in the operando photochemical cell). The initial rates of $\mathrm{H}_{2}$ evolution (in $\mathrm{mmol} \mathrm{g}_{\mathrm{cat}}{ }^{-1} \mathrm{~h}^{-1}$ ) are also reported.

\subsection{Photocatalytic activity}

The photocatalytic activity of $\mathrm{Pt} / \mathrm{g}-\mathrm{C}_{3} \mathrm{~N}_{4}$-ns and $\mathrm{Pt} / \mathrm{TiO} \mathrm{O}_{2}$ was determined for HER in a conventional photoreactor as well as in the operando photochemical setup. Fig. 5(a) and (c) show the photocatalytic activity of $\mathrm{TiO}_{2}$ and $\mathrm{g}-\mathrm{C}_{3} \mathrm{~N}_{4}$-ns, respectively, in the conventional photoreactor. The measured rates of $\mathrm{H}_{2}$ evolution were $16.6 \mathrm{mmol} \mathrm{g}^{-1} \mathrm{~h}^{-1}$ on $\mathrm{Pt} / \mathrm{TiO}_{2}$ under UV light illumination and $1.76 \mathrm{mmol} \mathrm{g}^{-1} \mathrm{~h}^{-1}$ on $\mathrm{Pt} / \mathrm{g}-\mathrm{C}_{3} \mathrm{~N}_{4}$-ns under visible light illumination. Fig. 5(b) and (d) show the $\mathrm{H}_{2}$ evolution activity in the operando photochemical cell. The rate of $\mathrm{H}_{2}$ evolution was $12.1 \mathrm{mmol} \mathrm{g}^{-1} \mathrm{~h}^{-1}$ on $\mathrm{Pt} / \mathrm{TiO}_{2}$ and $1.01 \mathrm{mmol} \mathrm{g}^{-1} \mathrm{~h}^{-1}$ on $\mathrm{Pt} / \mathrm{g}-\mathrm{C}_{3} \mathrm{~N}_{4}$-ns. The $\mathrm{H}_{2}$ evolution rates obtained in the operando cell were slightly lower than those obtained in the conventional photoreactor. A possible reason for this is that in the photochemical cell, only the exposed surface of the catalyst is activated and there may be part of catalyst not illuminated by UV/visible light. In the conventional top-irradiated photoreactor, on the other hand, the catalyst is suspended in the solution and is continuously stirred during the reaction. This results in a more uniform illumination of the photocatalyst. The rates obtained in the operando photochemical cell are however comparable to those obtained in the conventional photoreactor.

\subsection{Operando XAS measurements}

3.3.1 Photodeposition of Pt nanoparticles. The XANES and EXAFS at Pt $\mathrm{L}_{\mathrm{III}}$-edge (11564 eV) were measured during the photodeposition of Pt nanoparticles on $\mathrm{g}-\mathrm{C}_{3} \mathrm{~N}_{4}$-ns using the operando photochemical cell. The XANES of Pt before illumination, during illumination, and after illumination, are shown in Fig. 6(a). The XANES of Pt before illumination was similar to that of $\mathrm{Pt}^{\mathrm{IV}}$ in $\mathrm{H}_{2} \mathrm{PtCl}_{6}$ aqueous solution. Upon illumination with visible light, the XANES measurements suggest reduction of $\mathrm{Pt}$ from $\mathrm{Pt}^{\mathrm{IV}}$ to $\mathrm{Pt}^{0}$, indicating the formation of $\mathrm{Pt}$ nanoparticles on the surface of $\mathrm{g}-\mathrm{C}_{3} \mathrm{~N}_{4}$-ns. Illumination was continued for $20 \mathrm{~min}$, after which, no significant changes in XANES were observed for five consecutive measurements. A linear combination fitting (LCF) was performed between $-30 \mathrm{eV}$ and $+50 \mathrm{eV}$ around the $\mathrm{Pt}^{\mathrm{IIII}_{I}}$-edge, using $\mathrm{Pt}^{0}$ and $\mathrm{Pt}^{\mathrm{IV}}$ references as standards, and the results are shown in Fig. 6(b).
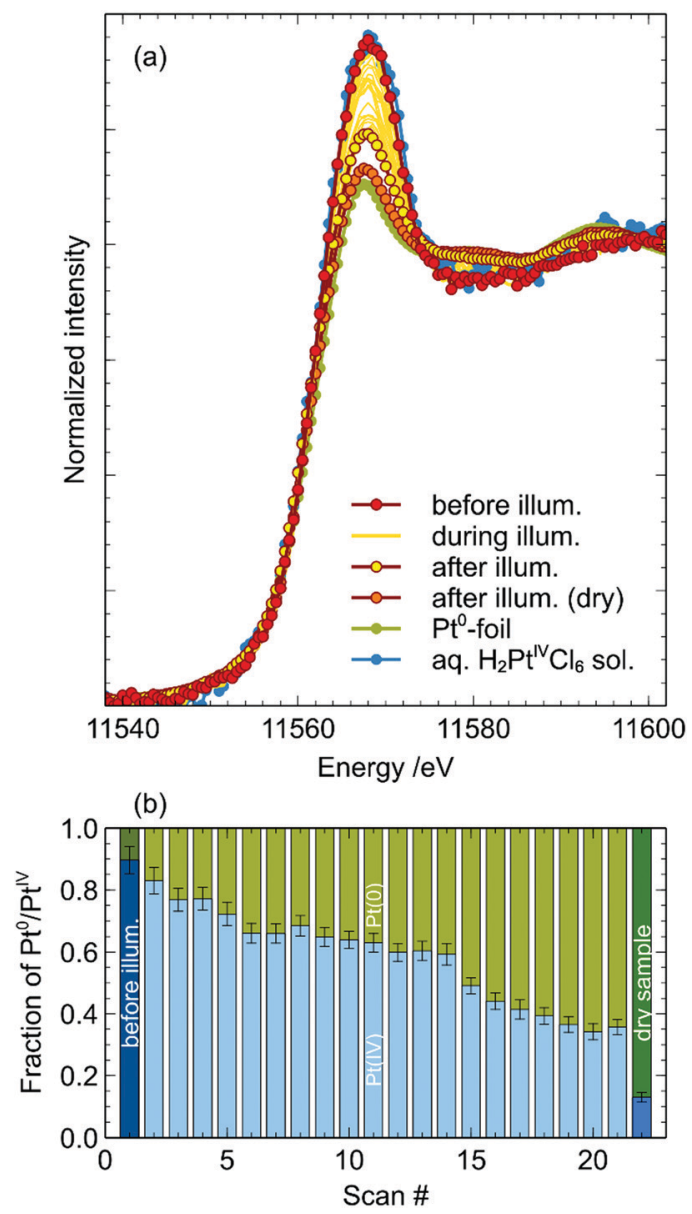

Fig. 6 (a) XANES of Pt nanoparticles at Pt $\mathrm{L}_{111}$-edge (11564 eV) during photodeposition of $\mathrm{Pt}$ on $\mathrm{g}-\mathrm{C}_{3} \mathrm{~N}_{4}$-ns using $\mathrm{H}_{2} \mathrm{PtCl}_{6}$ aqueous solution as a metal precursor. (b) Fraction of $\mathrm{Pt}^{\mathrm{IV}}$ and $\mathrm{Pt}^{\mathrm{O}}$ before illumination, during illumination, and in the dry sample, obtained from linear combination fitting.

Before illumination, Pt was present as $\sim 90 \% \mathrm{Pt}^{\mathrm{IV}}$ and $\sim 10 \%$ $\mathrm{Pt}^{0}$, suggesting partial reduction of $\mathrm{Pt}^{\mathrm{IV}}$ to $\mathrm{Pt}^{0}$ even before illumination was started. This observation can be attributed to the low band gap of $\mathrm{g}-\mathrm{C}_{3} \mathrm{~N}_{4}$-ns $\left(E_{\mathrm{g}} \sim 2.7 \mathrm{eV}\right)$. It is possible that $\mathrm{g}-\mathrm{C}_{3} \mathrm{~N}_{4}$-ns was activated under natural light, thereby 


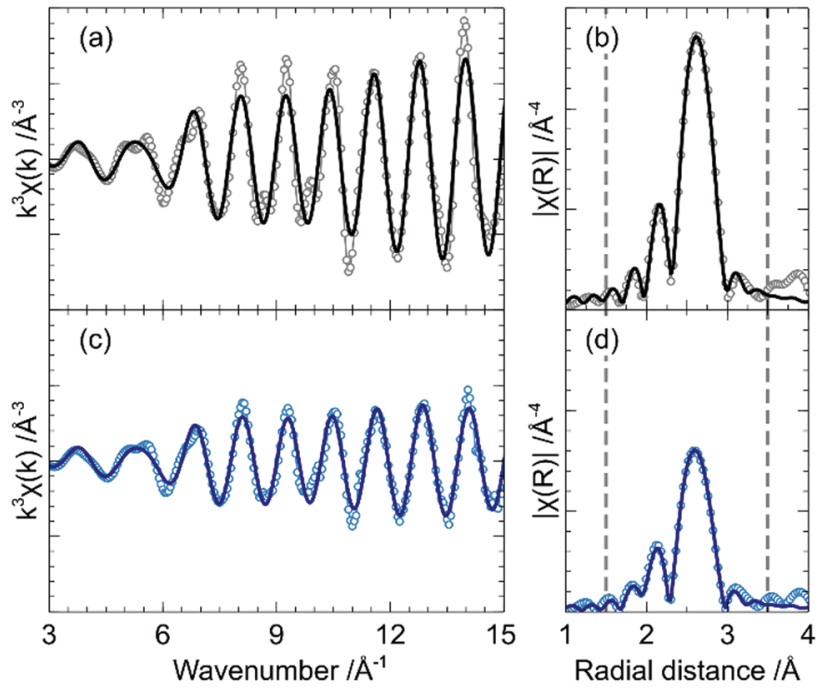

Fig. $7 \quad k^{3}$-Weighted EXAFS and Fourier-transformed EXAFS of: ( $a$ and $b$ ) Pt-foil, and ( $\mathrm{c}$ and d) $\mathrm{Pt} / \mathrm{g}-\mathrm{C}_{3} \mathrm{~N}_{4}$-ns (dry sample). Experimental data is shown as open symbols while the fitted curves are shown as solid lines.

Table 1 EXAFS fitting parameters: Pt-Pt coordination number $\left(\mathrm{CN}_{\mathrm{Pt}-\mathrm{Pt}}\right)$, $\mathrm{Pt}-\mathrm{Pt}$ interatomic distance $\left(d_{\mathrm{Pt}-\mathrm{Pt}}\right), \Delta E_{0}$, and $\sigma^{2}$, for (i) Pt-foil, and (ii) $\mathrm{Pt}$ nanoparticles deposited on $\mathrm{g}-\mathrm{C}_{3} \mathrm{~N}_{4}$-ns via photodeposition (Pt/g- $\mathrm{C}_{3} \mathrm{~N}_{4}-\mathrm{ns}$ ). The correlation between parameters (greater than 0.4 ) are also reported. $E_{0}$ was set to $11572 \mathrm{eV}$

\begin{tabular}{lrlrr}
\hline & \multicolumn{1}{c}{$\mathrm{CN}_{\mathrm{Pt}-\mathrm{Pt}}$} & \multicolumn{1}{c}{$d_{\mathrm{Pt}-\mathrm{Pt}} / \AA$} & \multicolumn{1}{c}{$\Delta E_{0} / \mathrm{eV}$} & $\sigma^{2} \times 1000 / \AA^{2}$ \\
\hline Pt-foil & $12.0 \pm 0.5$ & $2.764 \pm 0.002$ & $0.1 \pm 0.4$ & $4.67 \pm 0.16$ \\
Pt/g-C $\mathrm{C}_{3} \mathrm{~N}_{4}$-ns (dry) & $9.4 \pm 1.0$ & $2.745 \pm 0.005$ & $-0.8 \pm 1.0$ & $5.69 \pm 0.53$ \\
Correlation between parameters: $\sigma^{2}$ and $\mathrm{CN}_{\mathrm{Pt}-\mathrm{Pt}}=0.81-0.83, \Delta d_{\mathrm{Pt}-\mathrm{Pt}}$ and \\
$\Delta E_{0}=0.75-0.76$.
\end{tabular}

reducing $\mathrm{Pt}^{\mathrm{IV}}$ and resulting in the formation of Pt nanoparticles under $e x$ situ conditions prior to illumination. After illumination, $\mathrm{Pt}^{\mathrm{TV}}$ content continuously reduced and reached $36 \%$ when the measurements were stopped. The high $\mathrm{Pt}^{\mathrm{IV}}$ content is likely due to remaining $\mathrm{H}_{2} \mathrm{PtCl}_{6}$ aqueous solution in the cell. The cell was therefore drained of the remaining aqueous $\mathrm{H}_{2} \mathrm{PtCl}_{6}$ solution and XANES was measured once more (referred to as the dry sample). Upon decantation, $\mathrm{Pt}^{\mathrm{IV}}$ content further reduced to $\sim 13 \%$ with $\sim 87 \% \mathrm{Pt}^{0}$. The remaining $\mathrm{Pt}^{\mathrm{IV}}$ can be attributed to $\mathrm{H}_{2} \mathrm{PtCl}_{6}$ solution retained/absorbed on the g- $\mathrm{C}_{3} \mathrm{~N}_{4}$ nanosheets. It can however be concluded that Pt nanoparticles were formed on the surface of $\mathrm{g}-\mathrm{C}_{3} \mathrm{~N}_{4}$-ns upon illumination with visible light.

Fig. 7 shows the $k^{3}$-weighted EXAFS and Fouriertransformed EXAFS of Pt-foil and Pt nanoparticles formed on $\mathrm{g}^{-} \mathrm{C}_{3} \mathrm{~N}_{4}$-ns as a result of photodeposition. The corresponding EXAFS fitting parameters are reported in Table 1. The Pt-foil was first fitted to Pt fcc structure. The Pt-Pt coordination number $\left(\mathrm{CN}_{\mathrm{Pt}-\mathrm{Pt}}\right)$ in the Pt-foil was set to 12 (theoretical value based on the fcc structure) to obtain the amplitude reduction factor $S_{0}{ }^{2}=0.79$, which was subsequently used to fit Pt-Pt coordination shell in the Pt nanoparticles deposited on g- $\mathrm{C}_{3} \mathrm{~N}_{4}$-ns via photodeposition. The $E_{0}$ for Pt-foil measurement was set to $11572 \mathrm{eV}$ in order to obtain $\Delta E_{0}<1 \mathrm{eV}$ and the same value of $E_{0}$ was used in the fitting of Pt nanoparticles. The Pt-Pt interatomic distance $\left(d_{\mathrm{Pt}-\mathrm{Pt}}\right)$ in Pt-foil fitted to $2.764 \pm$ $0.002 \AA$, which is slightly lower than the theoretical value of $2.772 \AA$. The $\mathrm{CN}_{\mathrm{Pt}-\mathrm{Pt}}$ in Pt nanoparticles was found to be $9.4 \pm 1.0$ with $d_{\mathrm{Pt}-\mathrm{Pt}}$ equal to $2.745 \pm 0.005 \AA$. A $\mathrm{CN}_{\mathrm{Pt}-\mathrm{Pt}}$ of 9.4 corresponds to a spherical particle size of $\sim 2.5 \mathrm{~nm}$ and a dispersion $>60 \% .{ }^{48,49}$ These results show that photodeposition resulted in the formation of highly dispersed nanoparticles on the surface of g- $\mathrm{C}_{3} \mathrm{~N}_{4}$-ns.

3.3.2 Photocatalytic $\mathrm{H}_{2}$ evolution reaction. XANES measurements were performed on $\mathrm{Pt} / \mathrm{TiO}_{2}$ and $\mathrm{Pt} / \mathrm{g}-\mathrm{C}_{3} \mathrm{~N}_{4}$-ns under photocatalytic HER conditions using the operando photochemical cell. Fig. 8(a) and (b) show the XANES of Pt in $\mathrm{Pt} / \mathrm{TiO}_{2}$ and $\mathrm{Pt} / \mathrm{g}-\mathrm{C}_{3} \mathrm{~N}_{4}$-ns, respectively, under HER conditions. The Pt nanoparticles in $\mathrm{Pt} / \mathrm{TiO}_{2}$ and $\mathrm{Pt} / \mathrm{g}-\mathrm{C}_{3} \mathrm{~N}_{4}$-ns remained in metallic (reduced) $\mathrm{Pt}^{0}$ state during the reaction and there was no change observed in XANES upon illumination with UV or visible light. These results suggest that the active Pt-species during
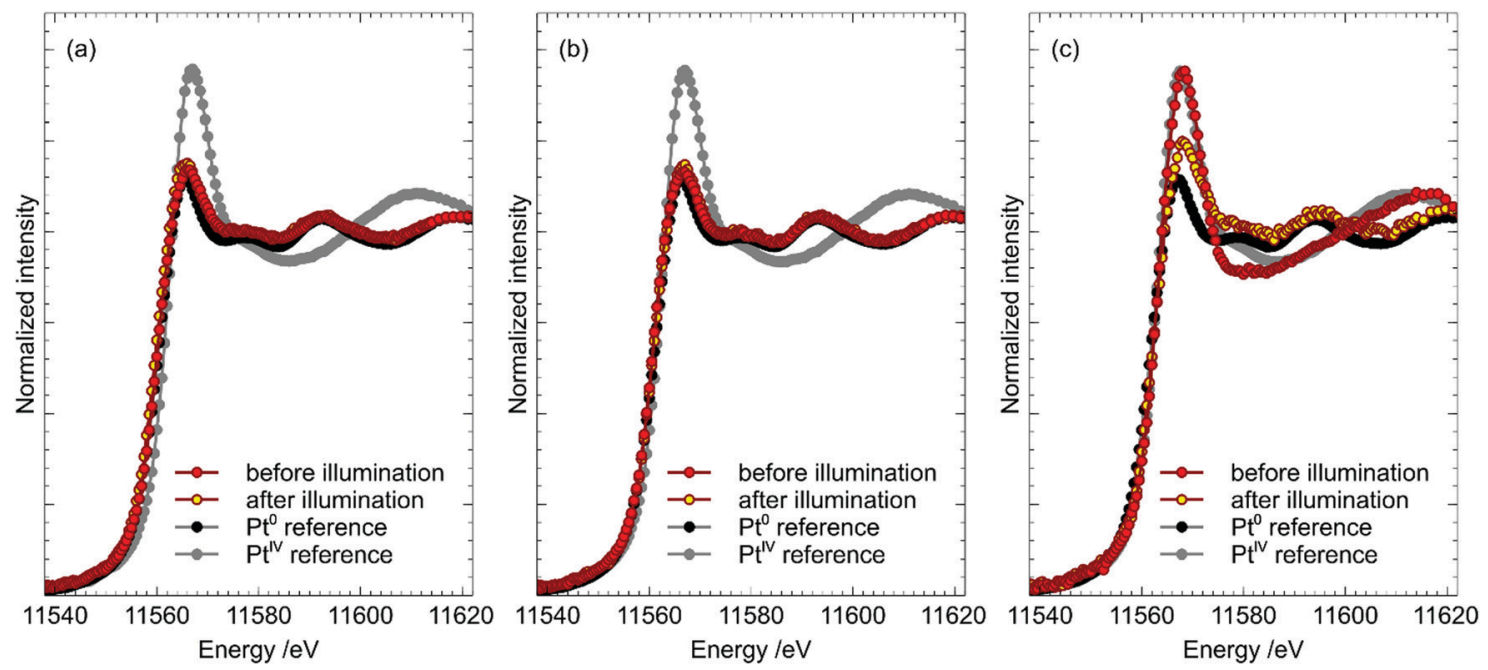

Fig. 8 XANES at Pt $\mathrm{L}_{11}$-edge (11564 eV) of (a) $\mathrm{Pt} / \mathrm{TiO}_{2}$, (b) $\mathrm{Pt} / \mathrm{g}-\mathrm{C}_{3} \mathrm{~N}_{4}-\mathrm{ns}$, and (c) $\mathrm{PtO}{ }_{x} / \mathrm{TiO}_{2}$, before and after illumination under $\mathrm{HER}$ conditions. 
photocatalytic HER conditions is $\mathrm{Pt}^{0}$. To further confirm the oxidation state of active Pt-species during HER, XANES measurements were also performed on $\mathrm{PtO}_{x} / \mathrm{TiO}_{2}$ photocatalyst. $\mathrm{PtO}_{x} /$ $\mathrm{TiO}_{2}$ was synthesized by treating $\mathrm{Pt} / \mathrm{TiO}_{2}$ in synthetic air $\left(20 \% \mathrm{O}_{2}\right.$ in $\mathrm{N}_{2}$ ) at $573 \mathrm{~K}$ for $8 \mathrm{~h}$. The temperature was increased from room temperature to $573 \mathrm{~K}$ at $1 \mathrm{~K} \mathrm{~min}^{-1}$ and held at $573 \mathrm{~K}$ for $8 \mathrm{~h}$ before cooling down naturally to room temperature. Fig. 8(c) shows the XANES of Pt in $\mathrm{PtO}_{x} / \mathrm{TiO}_{2}$ under HER conditions. It was observed that $\mathrm{Pt}$ reduced from $\mathrm{Pt}^{\mathrm{IV}}$ to $\mathrm{Pt}^{\mathrm{O}}$ upon illumination with UV light. Linear combination fitting using $\mathrm{Pt}^{0}$ and $\mathrm{Pt}^{\mathrm{IV}}$ reference spectra as standards showed that $\mathrm{Pt}^{\mathrm{IV}}$ content decreased from $\sim 96 \%$ before illumination to $\sim 33 \%$ after illumination, while $\mathrm{Pt}^{0}$ content increased from $\sim 4 \%$ to $\sim 67 \%$. This suggests that Pt did not completely reduce from $\mathrm{Pt}^{\mathrm{IV}}$ to $\mathrm{Pt}^{\mathrm{O}}$ upon illumination. It is possible that only the surface Pt atoms were reduced and the non-surface atoms within the Pt nanoparticles remained in the $\mathrm{Pt}^{\mathrm{IV}}$ oxidation state as $\mathrm{PtO}_{x}$. These results, however, confirm that the active Pt-species during photocatalytic HER is indeed metallic $\mathrm{Pt}^{0}$. The obtained results show that the operando photochemical cell can be used to (i) study photodeposition of nanoparticles, and (ii) determine the oxidation state of active species under photocatalytic reaction conditions.

3.3.3 Electrochemical hydrogenation of benzaldehyde. The operando electrochemical setup was used to investigate the oxidation state of Pd in Pd/C during ECH of $20 \mathrm{mM}$ benzaldehyde aqueous solution. XANES measurements at Pd K-edge (24350 eV) were performed on $\mathrm{Pd} / \mathrm{C}$ electrocatalyst under $\mathrm{OCV}$ and $\mathrm{ECH}$ reaction conditions $(-100 \mathrm{mV}$ or $-600 \mathrm{mV}$ vs. $\mathrm{Ag} / \mathrm{AgCl}$ reference electrode) and the results are reported in Fig. 9. It can be observed that $\mathrm{Pd}$ predominantly existed as metallic (reduced) $\mathrm{Pd}^{0}$ species under OCV as well as ECH reaction conditions. Linear combination

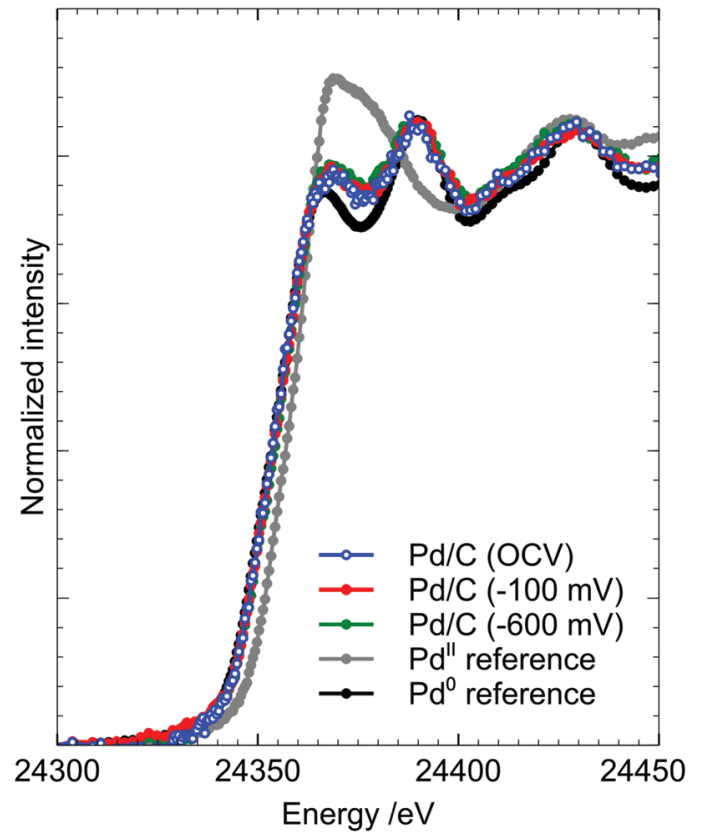

Fig. 9 XANES measurements at Pd K-edge (24350 eV) of Pd nanoparticles in $\mathrm{Pd} / \mathrm{C}$ at (i) OCV, (ii) $-100 \mathrm{mV}$ (vs. Ag/AgCl reference electrode), and (iii) $-600 \mathrm{mV}$ (vs. Ag/AgCl reference electrode), during $\mathrm{ECH}$ of benzaldehyde. fitting was performed on the experimental spectra between $-30 \mathrm{eV}$ and $+50 \mathrm{eV}$ around the Pd K-edge $(24350 \mathrm{eV})$ using $\mathrm{Pd}^{0}$ and $\mathrm{Pd}^{\mathrm{IV}}$ reference spectra as the two standards. The $\mathrm{Pd}$ in $\mathrm{Pd} / \mathrm{C}$ was observed to be mixture of $\sim 80 \pm 10 \% \mathrm{Pd}^{0}$ and $\sim 20 \pm 15 \% \mathrm{Pd}^{\mathrm{IV}}$. There was no significant difference in the observed $\mathrm{Pd}^{0} / \mathrm{Pd}^{\mathrm{IV}}$ composition in $\mathrm{Pd} / \mathrm{C}$ under OCV or ECH reaction conditions.

Fig. 10 shows the $k^{3}$-weighted EXAFS and Fouriertransformed EXAFS of Pd-foil and Pd/C under OCV and ECH reaction conditions. The EXAFS fitting parameters are reported in Table 2. The Pd-foil was fitted to Pd fcc structure. The Pd-Pd coordination number $\left(\mathrm{CN}_{\mathrm{Pd}-\mathrm{Pd}}\right)$ in the Pd-foil was set to 12 (theoretical value based on fcc structure) to obtain the amplitude reduction factor $\left({S_{0}}^{2}\right)$ of 0.74 . The same value of $S_{0}{ }^{2}$ was used in the fits for $\mathrm{Pd} / \mathrm{C}$ under $\mathrm{OCV}$ and $\mathrm{ECH}$ reaction conditions. The $E_{0}$ for Pd-foil measurement was set to $24352 \mathrm{eV}$ in order to obtain $\Delta E_{0}<1 \mathrm{eV}$ and the same value of $E_{0}$ was used in all subsequent fits. The Pd-Pd distance $\left(d_{\mathrm{Pd}-\mathrm{Pd}}\right)$ in Pd-foil
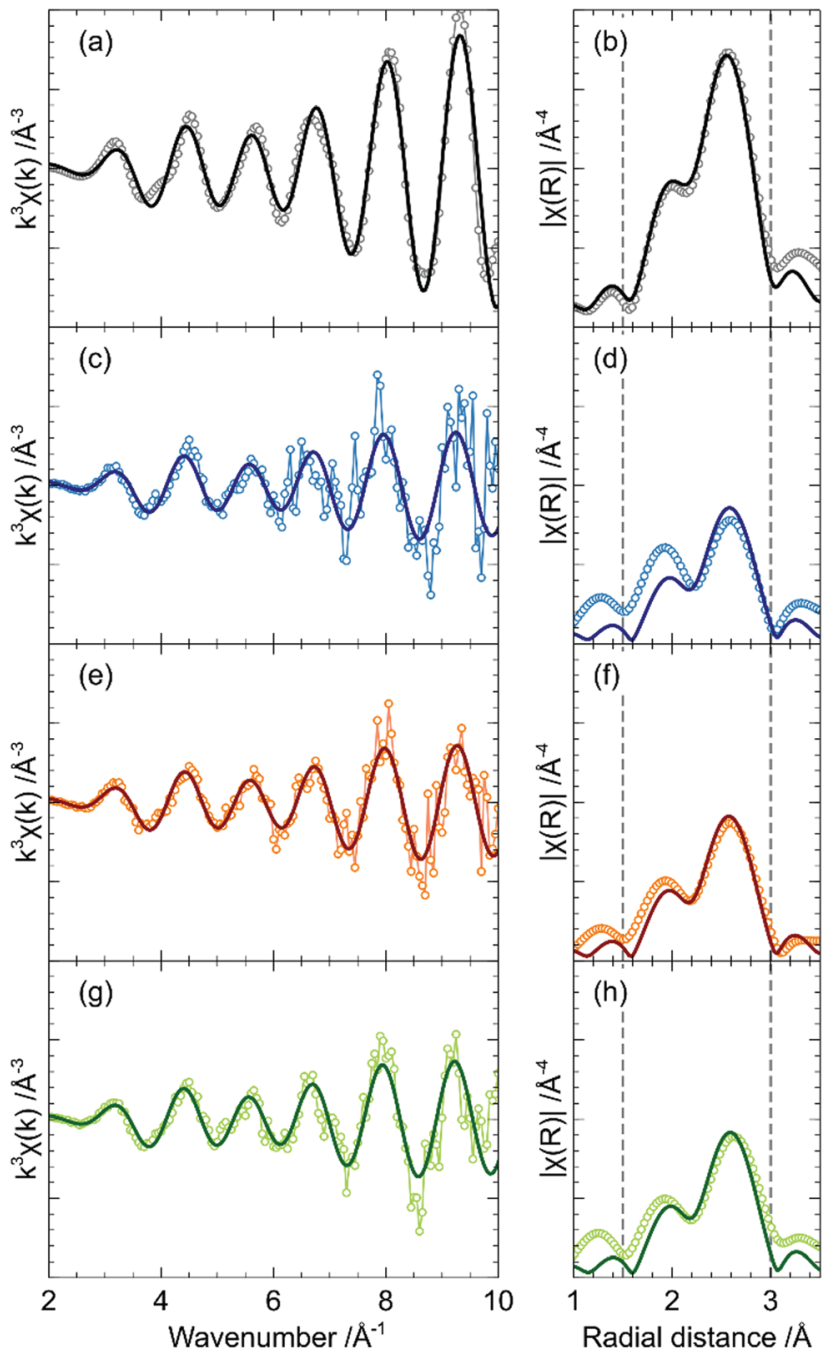

Fig. $10 \quad k^{3}$-Weighted EXAFS and Fourier-transformed EXAFS of: (a and $b$ ) $\mathrm{Pd}$-foil, (c and d) Pd/C at OCV, (e and f) Pd/C at $-100 \mathrm{mV}$ (vs. $\mathrm{Ag} / \mathrm{AgCl}$ reference electrode), and ( $\mathrm{g}$ and $\mathrm{h}$ ) $\mathrm{Pd} / \mathrm{C}$ at $-600 \mathrm{mV}$ (vs. $\mathrm{Ag} / \mathrm{AgCl}$ reference electrode), during $\mathrm{ECH}$ of benzaldehyde. Experimental data is shown as open symbols while the fitted curves are shown as solid lines. 
Table 2 EXAFS fitting parameters: $\mathrm{Pd}-\mathrm{Pd}$ coordination number $\left(\mathrm{CN}_{\mathrm{Pd}-\mathrm{Pd}}\right)$, $\mathrm{Pd}-\mathrm{Pd}$ interatomic distance $\left(d_{\mathrm{Pd}-\mathrm{Pd}}\right), \Delta E_{0}$, and $\sigma^{2}$, of (i) $\mathrm{Pd}$-foil, (ii) $\mathrm{Pd} / \mathrm{C}$ at $\mathrm{OCV}$, (iii) $\mathrm{Pd} / \mathrm{C}$ at $-100 \mathrm{mV}$ (vs. $\mathrm{Ag} / \mathrm{AgCl}$ reference electrode), and (iv) $\mathrm{Pd} / \mathrm{C}$ at $-600 \mathrm{mV}$ (vs. Ag/AgCl reference electrode), during $\mathrm{ECH}$ of benzaldehyde. The correlation between parameters (greater than 0.4 ) are also reported. $E_{0}$ was set to $24352 \mathrm{eV}$

\begin{tabular}{lllll}
\hline & $\mathrm{CN}_{\mathrm{Pd}-\mathrm{Pd}}$ & $d_{\mathrm{Pd}-\mathrm{Pd}} / \AA$ & $\Delta E_{0} / \mathrm{eV}$ & $\sigma^{2} \times 1000 / \AA^{2}$ \\
\hline $\mathrm{Pd}-$ foil & $12.0 \pm 0.5$ & $2.735 \pm 0.002$ & $0.4 \pm 0.3$ & $4.44 \pm 0.36$ \\
$\mathrm{Pd} / \mathrm{C}(\mathrm{OCV})$ & $10.1 \pm 26.0$ & $2.756 \pm 0.173$ & $0.2 \pm 17.7$ & $8.64 \pm 25.62$ \\
$\mathrm{Pd} / \mathrm{C}(-100 \mathrm{mV})$ & $10.4 \pm 24.5$ & $2.750 \pm 0.157$ & $0.2 \pm 16.2$ & $8.44 \pm 23.28$ \\
$\mathrm{Pd} / \mathrm{C}(-600 \mathrm{mV})$ & $10.6 \pm 21.9$ & $2.763 \pm 0.136$ & $0.4 \pm 14.2$ & $8.41 \pm 20.25$ \\
Correlation between parameters: $\sigma^{2}$ and $\mathrm{CN}_{\mathrm{Pd}-\mathrm{Pd}}=0.86-0.90, \Delta d_{\mathrm{Pd}-\mathrm{Pd}}$ \\
and $\Delta E_{0}=0.80-0.81$.
\end{tabular}

fitted to $2.735 \pm 0.002 \AA$, which is lower than the theoretical value of $2.751 \AA$. The $\mathrm{CN}_{\mathrm{Pd}-\mathrm{Pd}}$ in $\mathrm{Pd} / \mathrm{C}$ was determined to be $\sim 10.1$ at OCV and only increased slightly to $\sim 10.4$ at $-100 \mathrm{mV}$ (vs. $\mathrm{Ag} / \mathrm{AgCl}$ reference electrode) and to $\sim 10.6$ under $-600 \mathrm{mV}$ (vs. $\mathrm{Ag} / \mathrm{AgCl}$ reference electrode) external potential. These results suggest that the Pd nanoparticles were stable during ECH of benzaldehyde.

\subsection{Further applications}

The operando electrochemical cell and the gas-dosing and gas/ liquid-recirculation setup, being modular in nature, can be further modified for operando XAS measurements for photoelectrochemical experiments. The modified photo-electrochemical setup is described in detail in the ESI. $\dagger$

\section{Conclusions}

We have successfully developed and tested a photochemical cell and an electrochemical cell for operando XAS measurements during photocatalytic or electrocatalytic reactions. The operando photochemical setup was used to monitor the formation of Pt nanoparticles on graphitic carbon nitride, and the formation of highly dispersed Pt nanoparticles $(\sim 2.5 \mathrm{~nm}$ with $>60 \%$ dispersion) was observed. We also utilized this cell to determine the oxidation state of Pt under HER conditions and showed that the active Pt-species in $\mathrm{Pt} / \mathrm{TiO}{ }_{2}$ or $\mathrm{Pt} / \mathrm{g}-\mathrm{C}_{3} \mathrm{~N}_{4}-\mathrm{ns}$ were predominantly metallic (reduced) $\mathrm{Pt}^{0}$, and that $\mathrm{PtO}_{x}$ partially reduced from $\mathrm{Pt}^{\mathrm{IV}}$ to $\mathrm{Pt}^{\mathrm{O}}$ under these reaction conditions. We also showed that the rates of $\mathrm{H}_{2}$ evolution obtained in the operando photochemical cell $\left(12.1 \mathrm{mmol} \mathrm{g}^{-1} \mathrm{~h}^{-1}\right.$ on $\mathrm{Pt} / \mathrm{TiO}_{2}$ and $1.01 \mathrm{mmol} \mathrm{g}^{-1} \mathrm{~h}^{-1}$ on $\mathrm{Pt} / \mathrm{g}-\mathrm{C}_{3} \mathrm{~N}_{4}-\mathrm{ns}$ ) were comparable to those obtained in a standard top-irradiated photoreactor (16.6 $\mathrm{mmol} \mathrm{g}^{-1} \mathrm{~h}^{-1}$ on $\mathrm{Pt} / \mathrm{TiO}_{2}$ and $1.76 \mathrm{mmol} \mathrm{g}^{-1} \mathrm{~h}^{-1}$ on $\left.\mathrm{Pt} / \mathrm{g}-\mathrm{C}_{3} \mathrm{~N}_{4}-\mathrm{ns}\right)$. The operando electrochemical cell was also successfully utilized to determine the oxidation state of $\mathrm{Pd}$ in $\mathrm{Pd} / \mathrm{C}$ during electrochemical hydrogenation $(\mathrm{ECH})$ of benzaldehyde. It was observed that Pd predominantly existed as metallic (reduced) $\mathrm{Pd}^{0}$ in the form of stable $\mathrm{Pd}$ nanoparticles, which did not degrade upon the application of negative potential $(-100 \mathrm{mV}$ or $-600 \mathrm{mV}$ vs. $\mathrm{Ag} / \mathrm{AgCl}$ reference electrode) under ECH reaction conditions.

\section{Conflicts of interest}

The authors declare no conflicts of interest.

\section{Acknowledgements}

This work was supported by BMBF project MatDynamics (Verbundprojekt 05K13W03). The XAS measurements were performed at the P65 beamline of DESY (Hamburg, Germany), a member of Helmholtz Association HGF, as a part of a long-term proposal (II-20180593: “Operando studies on photo-(electro-)catalysts under dynamic reaction conditions"). The authors would like to acknowledge support from Dr. Edmund Welter and other staff from the P64/65 beamlines at DESY, Hamburg.

\section{References}

1 B. R. Fingland, F. H. Ribeiro and J. T. Miller, Catal. Lett., 2009, 131, 1-6.

2 B. S. Clausen, G. Steffensen, B. Fabius, J. Villadsen, R. Feidenhans'l and H. Topsøe, J. Catal., 1991, 132, 524-535.

3 B. S. Clausen and H. Topsøe, Catal. Today, 1991, 9, 189-196.

4 V. F. Kispersky, A. J. Kropf, F. H. Ribeiro and J. T. Miller, Phys. Chem. Chem. Phys., 2012, 14, 2229-2238.

5 F. C. Meunier, Chem. Soc. Rev., 2010, 39, 4602-4614.

6 J. W. Couves, J. M. Thomas, D. Waller, R. H. Jones, A. J. Dent, G. E. Derbyshire and G. N. Greaves, Nature, 1991, 354, 465-468.

7 D. E. Doronkin, H. Lichtenberg and J.-D. Grunwaldt, in XAFS Techniques for Catalysts, Nanomaterials, and Surfaces, ed. Y. Iwasawa, K. Asakura and M. Tada, Springer International Publishing, 2017, pp. 75-89.

8 S. Hannemann, M. Casapu, J.-D. Grunwaldt, P. Haider, P. Trussel, A. Baiker and E. Welter, J. Synchrotron Radiat., 2007, 14, 345-354.

9 M. Steib, A. Jentys and J. A. Lercher, J. Phys.: Conf. Ser., 2016, 712, 012049.

10 C. La Fontaine, L. Barthe, A. Rochet and V. Briois, Catal. Today, 2013, 205, 148-158.

11 J.-D. Grunwaldt, M. Ramin, M. Rohr, A. Michailovski, G. R. Patzke and A. Baiker, Rev. Sci. Instrum., 2005, 76, 054104.

12 M. Bauer, G. Heusel, S. Mangold and H. Bertagnolli, J. Synchrotron Radiat., 2010, 17, 273-279.

13 U. Caudillo-Flores, M. J. Muñoz-Batista, A. Kubacka and M. Fernández-García, ChemPhotoChem, 2018, 2, 777-785.

14 L. Liu, C. Zhao, J. T. Miller and Y. Li, J. Phys. Chem. C, 2017, 121, 490-499.

15 Y. H. Li, C. Li and H. G. Yang, J. Phys. Chem. A, 2017, 5, 20631-20634.

16 R. K. Hocking, R. Brimblecombe, L.-Y. Chang, A. Singh, M. H. Cheah, C. Glover, W. H. Casey and L. Spiccia, Nat. Chem., 2011, 3, 461-466.

17 A. Braun, K. Sivula, D. K. Bora, J. Zhu, L. Zhang, M. Grätzel, J. Guo and E. C. Constable, J. Phys. Chem. C, 2012, 116, 16870-16875. 
18 C. H. M. van Oversteeg, H. Q. Doan, F. M. F. de Groot and T. Cuk, Chem. Soc. Rev., 2017, 46, 102-125.

19 K. Sauer, J. Yano and V. K. Yachandra, Coord. Chem. Rev., 2008, 252, 318-335.

20 J. Yano and V. Yachandra, Chem. Rev., 2014, 114, 4175-4205.

21 A. S. M. Ismail, Y. Uemura, S. H. Park, S. Kwon, M. Kim, H. Elnaggar, F. Frati, Y. Niwa, H. Wadati, Y. Hirata, Y. Zhang, K. Yamagami, S. Yamamoto, I. Matsuda, U. Halisdemir, G. Koster, B. M. Weckhuysen and F. M. F. de Groot, Phys. Chem. Chem. Phys., 2020, 22, 2685-2692.

22 D. K. Bora, P.-A. Glans, J. Pepper, Y.-S. Liu, C. Du, D. Wang and J. H. Guo, Rev. Sci. Instrum., 2014, 85, 043106.

23 N. Singh, M.-T. Nguyen, D. C. Cantu, B. L. Mehdi, N. D. Browning, J. L. Fulton, J. Zheng, M. Balasubramanian, O. Y. Gutiérrez, V.-A. Glezakou, R. Rousseau, N. Govind, D. M. Camaioni, C. T. Campbell and J. A. Lercher, J. Catal., 2018, 368, 8-19.

24 N. Watanabe, J. Morais and M. C. M. Alves, J. Electron Spectrosc. Relat. Phenom., 2007, 156-158, 164-167.

25 K. Nakanishi, D. Kato, H. Arai, H. Tanida, T. Mori, Y. Orikasa, Y. Uchimoto, T. Ohta and Z. Ogumi, Rev. Sci. Instrum., 2014, 85, 084103.

26 T. Binninger, E. Fabbri, A. Patru, M. Garganourakis, J. Han, D. F. Abbott, O. Sereda, R. Kötz, A. Menzel, M. Nachtegaal and T. J. Schmidt, J. Electrochem. Soc., 2016, 163, H906-H912.

27 M. W. Kanan, J. Yano, Y. Surendranath, M. Dincă, V. K. Yachandra and D. G. Nocera, J. Am. Chem. Soc., 2010, 132, 13692-13701.

28 T. E. Furtak, J. Electrochem. Soc., 1994, 141, 2369-2373.

29 A. Braun, S. Shrout, A. C. Fowlks, B. A. Osaisai, S. Seifert, E. Granlund and E. J. Cairns, J. Synchrotron Radiat., 2003, 10, 320-325.

30 H. J. King, M. Fournier, S. A. Bonke, E. Seeman, M. Chatti, A. N. Jumabekov, B. Johannessen, P. Kappen, A. N. Simonov and R. K. Hocking, J. Phys. Chem. C, 2019, 123, 28533-28549.

31 M. Farmand, A. T. Landers, J. C. Lin, J. T. Feaster, J. W. Beeman, Y. Ye, E. L. Clark, D. Higgins, J. Yano, R. C. Davis, A. Mehta,
T. F. Jaramillo, C. Hahn and W. S. Drisdell, Phys. Chem. Chem. Phys., 2019, 21, 5402-5408.

32 K. Cheaib, B. Maurice, T. Mateo, Z. Halime and B. LassalleKaiser, J. Synchrotron Radiat., 2019, 26, 1980-1985.

33 Y. Gorlin, B. Lassalle-Kaiser, J. D. Benck, S. Gul, S. M. Webb, V. K. Yachandra, J. Yano and T. F. Jaramillo, J. Am. Chem. Soc., 2013, 135, 8525-8534.

34 C. Gutiérrez and C. Melendres, Spectroscopic and Diffraction Techniques in Interfacial Electrochemistry, 1990.

35 D. Lützenkirchen-Hecht and H.-H. Strehblow, Surf. Interface Anal., 2006, 38, 686-690.

36 B. J. Hwang, Y. W. Tsai, L. S. Sarma, C. H. Chen, J. F. Lee and H. H. Strehblow, J. Phys. Chem. B, 2004, 108, 15096-15102.

37 P. Borthen, B.-J. Hwang, H.-H. Strehblow and D. M. Kolb, J. Phys. Chem. B, 2000, 104, 5078-5083.

38 G. S. Frankel, A. G. Schrott, A. J. Davenport, H. S. Isaacs, C. V. Jahnes and M. A. Russak, J. Electrochem. Soc., 1994, 141, 83-90.

39 M. Nagasaka, H. Yuzawa and N. Kosugi, J. Electron Spectrosc. Relat. Phenom., 2015, 200, 293-310.

40 M. G. Dowsett and A. Adriaens, Anal. Chem., 2006, 78, 3360-3365.

41 K. Sasaki, N. Marinkovic, H. S. Isaacs and R. R. Adzic, ACS Catal., 2016, 6, 69-76.

42 B. Ohtani, O. O. Prieto-Mahaney, D. Li and R. Abe, J. Photochem. Photobiol., A, 2010, 216, 179-182.

43 T. Ohno, K. Sarukawa, K. Tokieda and M. Matsumura, J. Catal., 2001, 203, 82-86.

44 L. Yang, X. Liu, Z. Liu, C. Wang, G. Liu, Q. Li and X. Feng, Ceram. Int., 2018, 44, 20613-20619.

45 Y. Li, M.-Q. Wang, S.-J. Bao, S. Lu, M. Xu, D. Long and S. Pu, Ceram. Int., 2016, 42, 18521-18528.

46 E. Welter, R. Chernikov, M. Herrmann and R. Nemausat, AIP Conf. Proc., 2019, 2054, 040002.

47 B. Ravel and M. Newville, J. Synchrotron Radiat., 2005, 12, 537-541.

48 A. Jentys, Phys. Chem. Chem. Phys., 1999, 1, 4059-4063.

49 M. Vaarkamp, Catal. Today, 1998, 39, 271-279. 